\title{
Chewable Tablet Dosage Form
}

National Cancer Institute

\section{Source}

National Cancer Institute. Chewable Tablet Dosage Form. NCI Thesaurus. Code C42893.

A tablet that must be chewed to release the active and/or inert ing redient(s). 